\title{
AN OVERVIEW OF NORMATIVE DOCUMENTS ON TAXATION ISSUES FOR AUGUST-SEPTEMBER 2013
}

\author{
L.Anisimova
}

In August and September 2013, work continued on the Draft Federal Budget for 2014. As the RF Ministry of Finance had managed to ensure the timely preparation of alterations to tax legislation whereby the rates of export customs duties on hydrocarbons are to be reduced, and the rates of Mineral Extraction Tax increased, the Draft Budget was composed with those alterations being taken into consideration ${ }^{1}$. The RF Supreme Arbitration Court continued to methodologically clarify the application of tax legislation by Russia's judicial system, which would make it possible to improve the quality of judicial decisions and to reduce the number of errors in lawsuit consideration in courts of first instance.

The main problems that the Russian economy is faced with are stagnation in the production sphere, ongoing capital outflow, and accelerated growth of foreign debt. Unfortunately, the attempts to stabilize the Russian Federation's government debt at the level recommended by the International Monetary Fund (IMF) (10\% of GDP) have failed ${ }^{2}$; the debt issues faced by the regions are even more serious ${ }^{3}$. As for the

1 V. Visloguzov. Gosduma smeshala neft' s gazom. Vlasti zavershili uglevodorodnye nalogovye manevry [The State Dume Mixes Oil with Gas. The Authorities Have Completed Their Hydrocarbon Tax Maneuvers'. Kommersant, No 172/P (5203), 23 September 2013.

The RF Government managed to elaborate a single formula for calculating tax on mineral resources extraction for gas, which is very important for creating competitive conditions on the domestic market in the gas extraction sector. 'From 1 July 2014 the currently applied fixed (ruble-denominated) tax rates will be replaced by payments calculated with due regard for gas composition, prices on gas supply markets, transportation costs, export duties on oil, the share of gas supply on the domestic market, the average USD-to-ruble exchange rate, and a number of other parameters. All these variables incorporated in special formulae will increase or decrease the basic rate of tax on mineral resources extraction, which is set at $\mathrm{Rb} 35$ per thousand $\mathrm{m}^{3}$ of raw material'. The rate of tax on mineral resources extraction for oil will amount, in 2014, to $493 \mathrm{Rb} / \mathrm{ton}$, in 2015 - to $530 \mathrm{Rb} /$ ton., in 2016 - to $559 \mathrm{Rb} /$ ton against the current rate of $\$ 470$. In the formula for calculating the duty on oil (29.2 USD/ton + $60 \%$ of the difference between the monitoring price and $\$ 182.5$ ), the percentage-based component will be decreased to $59 \%$ in 2014, to $57 \%$ in 2015 , and to $55 \%$ in 2016.

2 Minfin: gosdolg RF uvelichitsia s 12\% VVP v GDP 2013 g. do 14,3\% VVP GDP v 2016 g. [The RF Ministry of Finance: RF Government Debt Will Increase from 12\% of GDP in 2013 to $14.3 \%$ of GDP in 2016]. See www.ng.ru, 18 September 2013.

'The RF Ministry of Finance expects RF government debt to increase from $12 \%$ of GDP, or Rb 8.116 trillion, in 2013 to $14.3 \%$ of GDP, or Rb 12.416 trillion, in 2016 ... The volume of external debt... will increase from $\mathrm{Rb} 2.063$ trillion in 2013 to $\mathrm{Rb} 3.081$ trillion in 2016. Internal debt will be growing at a higher rate - from $\mathrm{Rb} 6.053$ trillion in 2013 to Rb 9.336 trillion in 2016'.

3 "Izvestiia": k 2015 g. v Rossii poiaviatsia pervye regiony-bankroty [Izvestiia [The News]: by 2015 , the first bankrupt regions will appear in Russia]. See Gaseta.ru, 19 September 2013. foreign debt of the private sector, experts offer different interpretations of the existing situation. Thus, in particular, some experts believe that the loans attracted by Russian organizations are often fictitious in nature ${ }^{4}$. One may well agree with the view that fictitious debt growth serves as a cover for applying tax optimization schemes; however, at the same time the statements that such measures are not fraught with grave economic consequences for Russia's economy can hardly be regarded as believable. Let us explain our standpoint.

Shareholders are interested not so much in developing production as in maintaining and increasing equity (or their personal capital). So, in a situation of crisis, they do not think about production modernization - instead, their main concern is how to withdraw their personal equity into a 'safe harbor'. Development and modernization are usually the result of a successful resolution of a conflict concerning the valuation of a company's assets between its new and former owners - in favor of the new owner. Therefore an objective open market valuation of a company's equity is very important for the development of the entire economy. If proceeds begin to decline, all other conditions being equal, the company's owner evidently needs to sell it promptly, because afterwards its exchange value will dwindle. For a former owner, lower equity value means a capital loss, while for a new one a lower purchase price of a company means an opportunity to reduce the cost price of its products and to increase the efficiency of production, and even to stimulate capital growth. So, an objective valuation procedure

4 M. Papchenkova. Rossiia beriot vzaimy ochen' skhematicheski [Russia borrows very schematically]. 'The external debt of Russian companies is growing, although the economy is slowing down. The RF Ministry of Finance is worried - but it has no reason to be', believe experts from Interfax - Center of Economic Analysis (InterfaxCEA), 'this is not investment, this is tax economy'. See www.vedomosti.ru, 2 September 2013, 159 (3421). 
for determining the open market value of an enterprise is important primarily for investors. In Russia, privatization gave rise to a very unfavorable situation where, in the majority of sectors, a limited group of big shareholders exercise control over production. Such 'personally owned' companies are not available for fair open market valuation. Unfortunately, the initial owners of privatized enterprises are not aiming at safeguarding their invested capital (in fact, they have invested nothing) - instead, they want to 'squeeze' capital out of the assets that they have managed to grab. An economy with a large number of big 'personally owned' production entities is archaic in nature. The World Bank and International Monetary Fund have noted many times that, in a modern economy, 'personally owned' production is represented in the main by small and medium-sized businesses. So, regretfully, we must admit that, in Russia's present situation, tax optimization schemes are aimed not at increasing production volumes - their purpose is only to increase the personal capital of company owners by means of draining the production capacities of the companies that they have been fortunate enough to appropriate.

Ineffective production is much more than just a headache for shareholders - it implies wasting all the resources (human and material) in the territory of a given country. Therefore, no government should tolerate ineffective production entities operating in the territory under its jurisdiction. In a modern market, as we have already noted elsewhere, the role of personnel have altered - priority is now given to the economic relations between employees and manufacturers (legal entities), the purpose of such relations being to generate maximum market income, and then to distribute it between the manufacturer and personnel. In this connection, the role of equity is increasingly becoming that of a tool for continual valuation of companies through the stock exchange mechanism by setting market prices for securities and searching for new income-generating products and projects. In terms of law, the role and status of a legal entity (manufacturer) in a country's economy must also undergo certain changes. Similarly to the way that the State, in civilized society, protects the rights of legally incapable persons (including children), it must also elaborate the rules for protecting legal entities (manufacturers) from their 'parents' (shareholders) or those why by chance may 'adopt' them on the exchange and then ruin them in order to increase the 'foster parent's' personal capital. If the service capacity of fixed assets is exhausted, resources spent, debts too heavy for restoring an effective production process, the personnel will leave, and the legal entity - be liquidated. Its capitalist owner will not effectuate the liquidation because it will mean a loss of time and money, and so special structures are needed for undertaking that task. It is the government's function - to identify ineffective production entities and then to initiate the judicial proceedings necessary for liquidating them. The government must develop criteria for enforced restructuring or liquidation of ineffective production entities, with restrictions being imposed on their owners' rights - as it happened, for example, in the course of restructuring those Russian banks that were shattered by the 1998 crisis. It should be noted that Russia has already gained some positive experience of economic recovery of certain big banks, carried out by the Agency for Restructuring Credit Institutions (ARKO) ${ }^{1}$ without damage to the smooth running of the entire banking system.

At the present stage of development, the government must pursue the goal of speeding up the transition of tangible assets and human resources from poorly performing producers to efficient ones. Banks must also bear responsibility for issuing loans to ineffective production entities - the sums of bad loans that are not redeemed for a very long time must be written off against their reserves, in an enforced procedure, from the balance sheets of the banks that have issued them to the balance sheet of the Deposit Insurance Agency (DIA) or another entity empowered to supervise this type of activities (thereby thus, naturally, reducing the capitalization of the bank that has allowed thus delay in loan repayment). These claims must then be presented to the relevant debtors for redemption against their property, the ultimate measure being the initiation of proceedings in bankruptcy or bankruptcy administration, with open market revaluation of their assets.

Capital is flowing out of Russia because the State, fearing an upsurge in unemployment, does not allow sale of assets on the market at their real market price, thus artificially maintaining the operation of ineffective production entities at the expense of raw material export revenues. However, such situations can be resolved by applying certain well-known mechanisms: for example, a foreign company may be allowed to operate on the domestic market in the framework of a joint venture (with Russian legal entities), with a legally established quota for hiring Russian citizens and a legally established level of their earnings. No doubt, this can be interpreted as a de facto tax on access of foreign organizations into Russia's territory. Nevertheless, such schemes are applied across the globe, and so we must explore the possibility of introducing

1 The Agency for Restructuring Credit Institutions was liquidated in connection with the establishment of the Deposit Insurance Agency (DIA). 
similar arrangements in Russia - among other things, in situations of market sale of ineffective production entities (at the same time, strategic entities, in accordance with the law, will remain property of the State, while natural resources are jointly owned by the Federation and its subjects). The longer the issue of artificial preservation of ineffective production entities remains unresolved, the more difficult it will become to provide adequate solutions to the unemployment issue 1 (in a non-market economy, unemployment is latent; but it may begin instantly to aggravate in a situation when the government is no longer capable of providing financial backing for ineffective production entities, while no incentives are created for the emergence of new efficiently performing companies).

With due regard for the aggravating problems in the sphere of government finance, in the period under consideration the government adopted several documents in order to provide more thorough methodological substantiation for the issue of regulating the revenue base of budgets and mandatory payments.

1. By RF Government Decree of 18 September 2013, No 819 alterations are introduced into the procedures for preparing financial and economic substantiation for measures envisaged in drafts of normative legal acts. In particular, the provision concerning the financial and economic calculations, on which those drafts are to be based, has been formulated more precisely.

From now on, the drafts of normative legal acts designed to influence the level of revenue or expenditure of a given budget within the RF budgetary system (with a corresponding financial and economic substantiation, the relevant amounts being expressed in thousand rubles) are to be submitted to the RF Ministry of Finance, which in its resolution must provide a wellfounded estimation of the influence of such measures on the revenue or expenditure of a relevant budget.

In a similar manner, the wording of Item 12 of the Main Requirements to the Concept and Elaboration of Draft Federal Laws approved by RF Government Decree of 2 August 2001, No 576. The draft laws envisaged in Part 3 of Article 104 of the RF Constitution (meaning draft laws concerning the introduction or abolition of taxes, tax exemptions, issuance of government loans, changes to government financial liabilities, and other draft laws concerning the regulation of expenditures covered by the federal budget) from now on may be submitted to the RF State Duma only if the said finan-

$1 \quad$ I. Naumov. Biznes rezhet shtaty po zhivomu. V obrabatyvaiushchikh otrasliakh predpriiatia vynuzhdeny sokrashchat' sotrudnikov. [Businesses make ruthless personnel cuts. Companies in the manufacturing industry are forced to dismiss their employees]. See ng.ru 3 September 2013. cial and economic substantiation and the corresponding resolution are available (previously, the wording was more general - if the RF Government's resolution is available).

2. The RF Supreme Arbitration Court (RF SAC) is carrying on large-scale work aimed at technical adaptation of RF legislation and law enforcement practice to open market conditions. In this connection, it develops sufficiently adequate, logical and correct methodological approaches designed to protect the interests of the Russian Federation within the system of international economic relations in the private sector.

Thus, in order to improve the performance of judicial bodies and reduce the number of cases submitted to courts of second instance, the RF SAC is systematizing the requirements to legal suits, preparing methodological guidelines for dealing with typical situations arising whenever it becomes necessary to apply tax legislation, and developing normative legal substantiations for the issuance of relevant court rulings. These methodological guidelines are very important for increasing the independence of courts of justice when considering each specific case, and for shortening the period of court proceedings.

On 27 August 2013, Decree of the RF SAC plenary session of 30 July 2013, No 57 was posted to the RF SAC's website. In the preamble to the Decree it is stated that the latter is issued on the basis of Article 13 of the Federal Constitutional Law "On Arbitration Courts in the Russian Federation' in order to explain the issues arising in judicial practice and to ensure uniform approaches to the resolution of disputes arising in connection with the application of provisions stipulated in Part One of the RF Tax Code (RF TC).

The Decree focuses on the norms regulating the activities of tax agents, the procedural aspects of tax audits, law enforcement measures, suspension of taxpayers' bank accounts, application of tax exemptions and sanctions, execution of tax liabilities, tax control measures, execution of the decisions made by a tax agency, filing of appeals against the decisions made by tax agencies to a superior tax agency or a court of justice, etc.

For example, in accordance with the RF SAC plenary session's explanations with regard to Articles 24 and 46 of the RF Tax Code, a tax agent must transfer to the relevant budget the amount of tax that the said tax agent is liable to pay. This liability may be enforced by means of collecting from the tax agent the amount of tax due to be paid that has not been transferred to the budget, as well as the relating fines, in instances when a tax agent has collected the amount of tax in question from a taxpayer but failed to actually transfer 
it to the budget. Considering the compensatory function of fines as the payments designed to compensate the treasury for losses incurred as a result of failure to pay taxes in due time, the tax agent that has failed to deduct tax from a taxpayer's monies, may be forced to pay fines for the period from the date on which tax was to be collected and transferred to the budget until the date on which tax was to be paid directly by the taxpayer in accordance with the results of a relevant tax period. At the same time, these rules are not applicable if money is paid to a foreign person, because such person is not registered with Russian tax agencies and so is not subject to tax administration. Consequently, in an event of failure to deduct tax from monies paid to a foreign person, the tax agent may be made liable to pay both the amount of tax and the amount of fines changed for the period until the date on which the execution of tax liability is due.

An important explanation is offered with regard to tax exemptions. A taxpayer may take advantage of the right to a tax exemption that has not been applied during previous tax periods by submitting an adjusted tax declaration, an application in the framework of an on-site tax audit (relative to exemptions pertaining to the object of a given tax audit and tax period), or an application to tax agency when paying tax on the basis of tax notification.

If the liability to pay tax arises for an organization or individual entrepreneur as a result of an audit conducted by the Federal Tax Service in connection with transactions concluded between mutually dependent persons, tax is to be collected in a judicial procedure (Items 4 and 2 of Article 45 of the RF Tax Code).

In an event when the funds of an organization being liquidated are insufficient, its founders (or participants) are obliged to pay the remaining sum of taxes, duties, penalties and fines within the limits and in accordance with the procedure established by RF legislation (Item 2 of Article 49 of the RF Tax Code). However, this obligation may be enforced only in cases when, in accordance with civil legislation, the founders (or participants) bear subsidiary responsibility with regard to the debts of the organization being liquidated.

One more area addressed by the RF SAC in the framework of preparing methodological explanation for applying tax legislation is the analysis of letters and instructions issued by the RF Ministry of Finance and the Federal Tax Service for an unspecified range of persons (at present, such letters and instructions are qualified to be normative documents).

Here are some examples.

Open-end Joint-stock Company Avtoframos, Closed Joint-stock Company Volvo Vostok, Limited Liability Company Oriflame Cosmetics filed an appeal to recog- nize the order issued by the Federal Tax Service of 27 July 2012, No MMV-7-13/524@ 'On Approving the Notification Form Concerning Controlled Transactions, the Procedure for Filling in the Form, and the Format for the Submission, by a Taxpayer, of an Electronic Notification on Controlled Transactions' to be partly invalid for the reason of it being incompatible with the RF Tax Code. By its Ruling of 16 September 2013, No 10012/13 the RF SAC rejected the appeal. One impressive feature of that ruling is the legal analysis of the Notification Form with regard to compatibility of the information to be entered into the specific form fields with the requirements stipulated in the RF Tax Code. Such an analysis, conducted by a superior court, of a technical document format elaborated by a branch federal department, represents the first precedent of its kind. However, its importance cannot be overestimated, because from now on (after the RF SAC's ruling with regard to the format for submitting data on controlled transactions developed by the Federal Tax Service and coordinated with the RF Ministry of Finance) any failure to comply with that format, or incomplete data entered into that format, will be treated by the RF judicial system as a violation of prevailing tax legislation. In our previous overview, we have already noted the role of violations of RF domestic legislation in the rulings passed by Russian courts with regard to liquidation of Russian legal entities.

Meanwhile, it should also be noted that an appeal may be filed against the ruling to the effect that it may be revised in a supervisory procedure.

The same systemic approach to building a uniform methodological base in the taxation sphere was demonstrated by the RF SAC when considering the appeal, by Renault Samara (an affiliation of Renault France), on recognizing to be null and void certain paragraphs in the Federal Tax Service's Letter of 12 August 2009, No ShS-22-3/634@ 'On the Procedure for Drawing Up Invoices by Tax Agents'.

On 12 September 2013, the RF SAC issued Ruling No 10992/13 whereby the Federal Tax Service's Letter was deemed to be compatible with the RF Tax Code. Thus, the RF SAC effectively conducted a legal expert's estimation of a departmental document's compatibility not only with the provisions of the RF Tax Code, but also with legislation on competition. Such an outcome is even more important because the Federal Tax Service, in its comment on the appeal, had noted that the plaintiff was incorrectly applying the norms stipulated in the RF Tax Code, thus incurring additional costs, and simply asked that the appeal be rejected.

However, the RF SAC made a different decision. It treated the letter issued by the Federal Tax Service as a normative act. The expert's estimation by the RF SAC 
resulted in the recognition of a departmental document to be a normative act compatible with the RF Tax Code, thus effectively incorporating it in the system of tax legislation. Later on, this ruling will prevent the filing of similar appeals by other tax agents of foreign organizations.

3. The qualitatively new level of dealing with explanatory documents issued by ministries and departments that has been demonstrated by the RF SAC implies stricter requirements to the legal backing for these documents, as well as for the answers to specific requests by taxpayers submitted to the RF Ministry of Finance and the Federal Tax Service. Their explanations must be based on the norms stipulated in the RF Tax Code; or, the various branch ministries and departments may, with a reference to the RF Tax Code, recommend specific solutions to taxpayers' problems. In actual practice, while a ministry may simply state its viewpoint with regard to a specific issue, this may be fraught with additional expenses for taxpayers. In the RF Ministry of Finance's Explanatory Letter of $23 \mathrm{Au}$ gust 2013, No 03-07-11/34617 on the procedure of levying VAT in an event of an enforced destruction of spoilt products in order to ensure production safety, the RF Ministry of Finance essentially only states its opinion. The Ministry believes that in a situation when it is necessary to destroy finished product in order to prevent, for example, an epidemic of a contagious animal disease, and such an act is ordered by decision of a RF subject, the amounts of incoming VAT accepted for deduction are not to be restored as part of tax liabilities.

Meanwhile, instead it could have been recommended to taxpayers that they should apply for a delayed payment of tax (or tax credit), which is fully compatible with the RF Tax Code, and then request that the RF Ministry of Finance inform them on the measures that it was intending to introduce in order to settle the situation in a procedure established by the RF Tax Code (if it plans to prepare the relevant alterations and then introduce them in tax legislation).

In a similar situation, the Federal Tax Service acted more consistently when, in its Letter of 3 September 2013 , No BS-4-11/15963 it recommended that its territorial administrations should apply to the legislative (representative) bodies of RF subjects and the representative bodies of municipal formations and request a legal settlement of the issue of exempting the physical persons - victims of the recent floods - from the payment, in 2013, of personal income tax, land tax and transport tax. In this connection the Federal Tax Service explained that, in accordance with Item 4 of Article 5 of the RF Tax Code, the legislative acts on tax- es and levies whereby taxes and/or levies can be abolished, or the rates of taxes and/or levies be reduced, or taxpayers, payers of levies, tax agents, or their representatives be relieved of their responsibilities, or the position of the said entities be improved in any other way, may become retroactive, if that possibility is explicitly stipulated therein. Normative acts must precisely establish the period from which exemptions are to be applied, the grounds for such exemptions (the titles of relevant documents and the bodies that have issued them), and the procedure for granting exemptions (with or without an application by a physical person).

4. The financial ministries and departments are also involved in elaborating methodology, meaning the issuance of letters and explanatory notes concerning specific instances of applying tax legislation. The task of offering explanations to taxpayers by federal ministries and departments is very important, because it boosts confidence in the government tax policy, helps prevent tax violations, and so brings down taxpayers' costs.

4.1. Letter of the Federal Tax Service of 9 September 2013, No ED-4-3/16239@, and Letter of the RF Ministry of Finance of 7 August 2013, No 03-03-10/31889 deal with the issue of applying the provisions stipulated in Items 7 and 8 of Article 262 of the RF Tax Code. These have to do with the 1.5 coefficient applicable to expenditures earmarked for research and development. This coefficient may be applied to actual expenditures on research and development established by the list approved by the RF Government Decree of 24 December 2008 , No 988 , and only with regard to the expenditure items specified in Subitems 1-5 of Item 2 of Article 262 of the RF Tax Code. In this connection, the profit tax declaration must be supplemented by a statement of a completed research and development project (or completed phases of a research and development project). If such a statement is not submitted, the amounts spent on research and development work (or specific phases of a research and development project) are to be considered as part of other expenditures, in their actual amount, without applying the coefficienta.

4.2. Letter of the RF Ministry of Finance and the Federal Tax Service of 3 September 2013, No ED-43/15954@ explains the procedure for making the established regular payments for the use of mineral resources. These payments are regulated by the Federal Law 'On Mineral Resources'. The payments are transferred for the granting, on the basis of a State license, of exclusive rights for surveying and assessment of deposits of mineral resources, exploration and estimation of land plots for the construction and exploitation of 
structures unrelated to mineral resources extraction, and construction and exploitation of underground structures unrelated to mineral resources extraction, with the exception of shallow underground engineering structures (up to 5 meters) for targeted use. The regular payments for the use of mineral resources are to be transferred on a quarterly basis, no later than the last day of the month following the relevant quarter, in equal installments in the amount of $1 / 4$ of the estimated annual payment.

4.3. Letter of RF Ministry of Finance of 15 August 2013, No 03-03-06/1/33242 explains the procedure for determining the purchase price of securities received by an organization as dividends. This document deserves special attention because the correspondent compares the treatment of the dividend payment transactions in the form of securities and property in several developed European countries and in Russian legislation. The analyzed approaches differ in that in European countries the payment of dividends in the form of property (including securities) is treated, on the one hand, as sale of property at a price determined by an independent valuator, while on the other hand, dividends are considered to be paid in an amount equal to the price of property being transferred, determined by the same independent valuator. In Russia, the property received in lieu of dividends in entered in the accounting records at its purchase price, i.e., in this case - this price is deemed to be equal to the amount of dividends declared by a shareholder meeting, and not to its market value. As a result, the budget incurs losses. 